\title{
The Development Process of Problem Based Learning Models Developed by Exposition Text Writing Materials on VIII Grade Students of Methodist 12 Medan
}

\author{
Putri Dewita Napitupulu' ${ }^{1}$ Mutsyuhito Solin², Abdurahman Adisaputera ${ }^{2}$ \\ ${ }^{1}$ Master Student in Universitas Negeri Medan (Unimed), Indonesia \\ ${ }^{2}$ Lecturer in Universitas Negeri Medan (Unimed), Indonesia \\ putrinapitupulu09@gmail.com
}

\begin{abstract}
This study is aimed to describe the development process of problem based learning models developed by exposition text writing materials on students. One of the models used by teachers in learning of exposition text writing was a problem based learning model. The teacher applies a problem based learning model in text learning but has obstacles when implementing the syntax of the learning model. This research was conducted at Junior high school of Methodist 12 Medan in July to August 2019. The research that has been carried out is a research and development that using the 4-D method which takes four stages of research, namely Define, design, development, and dissemination. The product of this research was in the form of developing the steps of a problem based learning model. The result shows that the aspects of the assessment given by reviewers, the product design of the problem based learning model development has been very good with an average score of overall acquisition of $80 \%$ with very good assessment criteria.
\end{abstract}

Keywords: development; problem based learning models; exposition text; students

\section{Introduction}

One of the text writing skills that must be learned by eighth grade junior high school students in the first semester is exposition text writing skills. Writing exposition text skills is one of the writing skills that serves to convey ideas and thoughts about a problem based on strong argumentation. Suparno (2008: 5) defines the text of the exposition as an essay whose primary purpose is to tell, peel, describe, or explain something. Exposition text contains opinions that want to be conveyed, the writing must also use sentences that are good and right.

Writing the exposition text in 2013 Curriculum is listed in Basic Competence 4.6, namely "Presenting ideas, opinions in the form of exposition text in the form of popular scientific articles (environment, social conditions, and / or cultural diversity, etc.) verbally and in writing with due regard to structure, linguistic elements, and oral aspects". Students are declared capable of writing exposition text if the text written by students includes clear information and is supported by complete and correct facts. In addition, students must pay attention to the elements of language and spelling in writing exposition text, and be able to write according to the structure of the exposition text, namely statements of opinion (thesis), arguments with well-structured, careful, and polite sentences so that they are easily understood and do not cause misinterpretation and reaffirming opinions appropriately.

But the reality that was found, the activity of writing the exposition text became something difficult and far from expectations. Based on the results of interviews and observations conducted with one of the Indonesian language teachers who teach at junior high school of Methodist 12 Medan, Mrs. Sariana Manurung, S.Pd., revealed that the average value of Indonesian daily tests has not yet reached the KKM score, especially in 
writing text material the exposition is 67 with $66 \%$ completeness. This condition shows that the students' understanding in the learning process of writing exposition texts is still low, causing the student learning outcomes to tend to be low. Facts on the field, the results of interviews with Indonesian language teachers revealed that the teacher had used strategies and models in learning Indonesian but had not caused students' interest to better understand exposition text material. One of the models used by teachers in learning to write text including exposition text writing is a problem based learning model. The teacher applies a problem based learning model in text learning but has obstacles when implementing the syntax of the learning model. Teachers who have tried the desired learning model, one of which is a problem-based learning model, but because teachers feel they have obstacles in implementing the syntax of the model, the teacher often slips into the traditional learning model.

\section{Review of Literature}

\subsection{Learning Model}

Learning model referred to in Permendikbud Number 103 of 2014 and Permendibud Number 22 of 2016 is a learning model that emphasizes activity and creativity, inspires, is fun and has initiative, is student-centered, authentic, contextual, and is meaningful to students' daily lives. In 2013 curriculum, the learning model is a conceptual framework that is used as a guideline for conducting learning that is arranged systematically to achieve learning objectives concerning syntax, social systems, reaction principles and support systems (Joice \& Wells). Meanwhile, according to Arends in Trianto (2018: 22), revealed that the learning model is a plan or pattern that is used as a guide in planning classroom learning or tutorial learning. The learning model refers to the learning approach that will be used, including teaching objectives, stages in learning activities, learning environment, and classroom management.

Learning model according to Rusman (2017: 133), states that learning model is a plan or pattern that can be used to shape the curriculum (long-term learning plan), design learning materials, and guide learning in class or other. Learning models can be presented in a choice pattern, meaning teachers can choose appropriate and efficient learning models to achieve their educational goals.

\subsection{Problem Based Learning Models}

Problem Based Learning (PBL) model is rooted in Jhon Dewey's belief in Abidin (2014: 158) that teachers must teach by appealing to students' natural instincts to investigate and create. Dewey writes that the main approach that should be used for every subject in school is the approach that is able to stimulate the minds of students to acquire all non-scholastic learning skills. Based on this belief, learning should always be linked to students' daily lives because this natural context provides something that students can do, not something that must be learned, so this will naturally require students to think and get natural learning outcomes as well. Based on this view PBL models subsequently developed into a problem-based learning model as the first thing that appears during the learning process. The problem is presented as natural as possible and then students work with problems that require students to apply their knowledge and abilities in accordance with the level of psychological maturity and learning ability. The concept of learning is then 
seen as a learning concept that is very in accordance with the demands of learning in the 21 st century that requires students to always develop thinking skills, problem-solving abilities, and the ability to carry out research as abilities needed in the context of a rapidly changing world.

\subsection{Exposition Text}

Lexical exposition comes from English "exposition" which means opening or starting. Based on the basic words, the nature of the exposition is a text that provides a detailed description of information. While the term exposition text according to Juhari (2013: 58) means a text that aims to inform, explain, peel, and describe something.

Dalman (2014: 119) argues that the exposition text is a text that describes the knowledge and experience of the author obtained from literature or field studies with the aim to add insight and reader knowledge about a matter.

Yesumi (2014: 160) said that exposition is a variety of discourse intended to explain or elaborate on things that can broaden or add to the knowledge and views of readers. While PriYatni (2014: 91) states that the exposition text is a text used to convince readers of opinions expressed with a number of supporting arguments. Exposition text usually contains an issue or issue on a particular topic and a statement that shows the author's position in responding to the issue or problem.

Keraf (1980: 3) states "exposition is one form of writing or rhetoric that seeks to explain and elaborate on a point of thought that can expand the views or knowledge of someone who reads the description." Exposition is a form of rhetoric that is often used in conveying descriptions popular science and other scientific descriptions which do not try to influence the opinions of others. Popular scientific papers in daily, weekly, and monthly magazines are usually presented in the form of exposition. The reader is not forced to accept the author's opinion at all. Every reader may refuse and accept what the author has stated. But at least the reader already knows that there are people who think or hold that opinion.

\section{Research Method}

This research was conducted at Junior high school of Methodist 12 Medan. This school was chosen with the consideration that no research has been conducted on the same problem as the problem in the research raised by the researchers at this time. The location of schools that are easily accessible and already using the 2013 curriculum is one of the reasons the researchers chose this location to facilitate the implementation of research. This research was conducted in July to August 2019.

\section{Discussion}

The research that has been carried out is a research and development that using the 4-D method which takes four stages of research, namely Define, design, development, and dissemination. Endang (2017: 1) in his research revealed "4-D Model is a model of research and development of learning systems consisting of Define, Design, Development, and Disseminate". 
The product of this research is in the form of developing the steps of a problem based learning model so that it produces a problem based learning model with nine steps in learning of exposition text writing.

At this stage a curriculum analysis is carried out in VIII grade of junior high school Methodist 12 Medan that is 2013 Curriculum. The 2013 curriculum aims to encourage students to be able to carry out scientific activities that are observing, asking questions, gathering information, creating, and communicating, so that students are active in learning activities.

Table 1. Observation Results Data at the Defining Stage Performed to Students

\begin{tabular}{|l|l|l|l|}
\hline No. & A list of questions & Answer & Frequency \\
\hline 1. & $\begin{array}{l}\text { The learning model that has been used by teachers in } \\
\text { learning of exposition text writing is interesting to } \\
\text { students. }\end{array}$ & $\begin{array}{l}\text { - Yes } \\
- \text { No }\end{array}$ & $\mathbf{0}$ \\
\hline 2. & $\begin{array}{l}\text { The learning model that has been used by teachers } \\
\text { can help students understand learning of exposition } \\
\text { text writing. }\end{array}$ & $\begin{array}{l}\text { - Yes } \\
\text { - No }\end{array}$ & $\begin{array}{l}\mathbf{0} \\
\mathbf{1 7}\end{array}$ \\
\hline 3. & $\begin{array}{l}\text { The learning model that has been used by teachers } \\
\text { can motivate students to learn exposition text writing } \\
\text { material. }\end{array}$ & $\begin{array}{l}\text { - Yes } \\
\text { - No }\end{array}$ & $\begin{array}{l}\mathbf{4} \\
\mathbf{1 3}\end{array}$ \\
\hline 4. & $\begin{array}{l}\text { Requires the use of developing problem-based } \\
\text { learning models in exposition text learning. }\end{array}$ & $\begin{array}{l}\text { - Yes } \\
- \text { No }\end{array}$ & $\begin{array}{l}\mathbf{1 3} \\
\mathbf{4}\end{array}$ \\
\hline 5. & $\begin{array}{l}\text { Happy with problem based learning. } \\
\text {-Yes } \\
\text { 6. No }\end{array}$ & $\begin{array}{l}\mathbf{1 3} \\
\mathbf{3}\end{array}$ \\
\hline & Be motivated to take part in learning by using a & $\begin{array}{l}\text { - Yes } \\
\text { problem based learning model. }\end{array}$ & $\begin{array}{l}\mathbf{1 4} \\
\mathbf{3}\end{array}$ \\
\hline
\end{tabular}

Table 2. Data of Observation Results at the Define Stage Performed by Teacher

\begin{tabular}{|c|c|c|c|}
\hline No. & A list of questions & Answer & Frequency \\
\hline 1. & $\begin{array}{l}\text { The teacher has used the learning model in delivering } \\
\text { exposition text writing material }\end{array}$ & $\begin{array}{l}\text { - Yes } \\
\text { - No }\end{array}$ & $\begin{array}{l}2 \\
\mathbf{0}\end{array}$ \\
\hline 2. & $\begin{array}{l}\text { The steps of the learning model used are interesting } \\
\text { and well used in learning. }\end{array}$ & $\begin{array}{l}\text { - Yes } \\
\text { - No }\end{array}$ & $\begin{array}{l}\mathbf{0} \\
\mathbf{2}\end{array}$ \\
\hline 3. & Presentation of steps in a systematic learning model & $\begin{array}{l}\text { - Yes } \\
\text { - No }\end{array}$ & $\mathbf{0}$ \\
\hline 4. & $\begin{array}{l}\text { The learning model presented helps students } \\
\text { understand the material to write exposition text. }\end{array}$ & $\begin{array}{l}\text { - Yes } \\
\text { - No }\end{array}$ & $\mathbf{0}$ \\
\hline 5. & $\begin{array}{l}\text { Learning models can be learned independently for } \\
\text { students. }\end{array}$ & $\begin{array}{l}\text { - Yes } \\
\text { - No }\end{array}$ & $\begin{array}{l}\mathbf{0} \\
2\end{array}$ \\
\hline
\end{tabular}

The assessment of development products from peers is an initial improvement given by colleagues (peers) who are teachers with the same educational qualifications. The reviewers were two teachers who both taught at Junior High School of Methodist 12, Medan, Nopalina Silitonga, S.Pd. and Sariana Manurung, S.Pd. In this stage the validator provides suggestions and improvements to the initial product design products that are introduced with the aim to improve the quality of problem-based learning models for exposition text writing material. The 
Budapest International Research and Critics in Linguistics and Education (BirLE) Journal Volume 2, No 4, November 2019, Page: 305-314

e-ISSN: 2655-1470 (Online), p-ISSN: 2655-2647 (Print)

www.bircu-journal.com/index.php/birle emails: birle.journal@gmail.com birle.journal.qa@gmail.com

revised results are in the form of an assessment score on the components of the lesson plan and teaching material in table 4.3 below:

Table 3. Peer Assessment Scores for Learning Design

\begin{tabular}{|c|c|c|c|}
\hline \multirow{2}{*}{ No } & \multirow{2}{*}{ Competence of Learning Implementation Plan } & \multicolumn{2}{|c|}{ Study Results / Scores } \\
\hline & & $\begin{array}{l}\text { Reviewer } \\
1\end{array}$ & $\begin{array}{l}\text { Reviewer } \\
2\end{array}$ \\
\hline \multicolumn{4}{|c|}{ Subject Identity } \\
\hline 1. & $\begin{array}{l}\text { There are educational units, classes, semesters, } \\
\text { programs, subjects or subject themes, number of } \\
\text { meetings }\end{array}$ & 4 & 4 \\
\hline \multicolumn{4}{|c|}{ Formulation of Indicators } \\
\hline 2. & Suitability of SKL, KI, and KD & 3 & 3 \\
\hline 3. & Suitability for use of operational words (KKO) & 3 & 3 \\
\hline 4. & $\begin{array}{l}\text { Conformity with aspects of attitude, knowledge, } \\
\text { and skills. }\end{array}$ & 3 & 3 \\
\hline \multicolumn{4}{|c|}{ Learning objectives } \\
\hline 5. & $\begin{array}{l}\text { Conformity with the process and expected learning } \\
\text { outcomes achieved. }\end{array}$ & 3 & 3 \\
\hline 6. & Conformity with basic competencies. & 4 & 4 \\
\hline \multicolumn{4}{|c|}{ Learning objectives } \\
\hline 7. & Conformity with learning objectives & 3 & 4 \\
\hline 8. & Conformity with the characteristics of students & 3 & 3 \\
\hline 9. & Conformity with time allocation & 3 & 3 \\
\hline \multicolumn{4}{|c|}{ Selection of Learning Resources } \\
\hline 10. & Compliance with CC and BC & 4 & 4 \\
\hline 11. & $\begin{array}{l}\text { Conformity with learning material and scientific } \\
\text { approach }\end{array}$ & 3 & 3 \\
\hline 12. & Conformity with the characteristics of students & 3 & 3 \\
\hline \multicolumn{4}{|c|}{ Learning Media Selection } \\
\hline 13. & Conformity with learning objectives & 4 & 3 \\
\hline 14. & $\begin{array}{l}\text { Conformity with learning materials and Scientific's } \\
\text { approach }\end{array}$ & 3 & 3 \\
\hline 15. & Conformity with the characteristics of students & 3 & 3 \\
\hline \multicolumn{4}{|c|}{ Learning model } \\
\hline 16. & Conformity with learning objectives & 4 & 4 \\
\hline 17. & Compliance with the Scientific approach & 3 & 3 \\
\hline \multicolumn{4}{|c|}{ Learning Scenarios } \\
\hline 18. & $\begin{array}{l}\text { Displays preliminary activities, core activities, and } \\
\text { concluding clearly. }\end{array}$ & 3 & 3 \\
\hline 19. & Compliance with the Scientific approach & 3 & 3 \\
\hline 20 & $\begin{array}{l}\text { Conformity of presentation with systematic } \\
\text { material }\end{array}$ & 3 & 3 \\
\hline 21. & $\begin{array}{l}\text { Suitability of time allocation with material } \\
\text { coverage }\end{array}$ & 3 & 3 \\
\hline
\end{tabular}




\begin{tabular}{|l|l|l|l|}
\hline \multicolumn{3}{|c|}{ Assessment / Evaluation } & 3 \\
\hline 22. & $\begin{array}{l}\text { Compliance with the techniques and forms of } \\
\text { authentic assessment }\end{array}$ & 3 & 3 \\
\hline 23. & $\begin{array}{l}\text { Compliance with indicators of competency } \\
\text { achievement }\end{array}$ & 3 & 3 \\
\hline 24. & The suitability of the answer key to the problem & 3 & 3 \\
\hline 25. & Compliance with scoring guidelines & 3 & $\mathbf{8 0}$ \\
\hline Total & $\mathbf{8 0}$ & \\
\hline Average Number of Scores & $\mathbf{8 0 \%}$ \\
\hline
\end{tabular}

Based on the amount of data obtained from the results of peer examinations (reviewer) obtained six indicators with very good criteria, and three other indicators with good categories, there are in the following:

1) The identity of subjects in the learning design gets score of eight with a percentage of $100 \%$ with very good criteria. The comments given are the identity of the subjects listed on the lesson plan product design complete with the name of the school, subject, class / semester, topic, and time allocation.

2) The formulation of the indicator gets score of 18 with a percentage of $75 \%$ with good criteria. Comments received in the form of suggestions and improvements to the selection of operational verbs used in formulating indicators of competency achievement.

3) Aspect of formulation of learning objectives gets score of 14 with a percentage of $87.50 \%$ and very good assessment criteria.

4) Evaluation of teaching material gets score of 19 from twenty-four maximum scores with a percentage of $79.16 \%$ and very good criteria. The comments received from colleagues are that the material presented is very adequate to achieve the competence of writing exposition texts.

5) The assessment aspect of learning resources gets a score of 20 with a percentage of $83.33 \%$ and the assessment criteria are good. In addition to using student textbooks published by the government, learning resources are also taken from other books especially involving the use of electronic media in the form of the internet to enrich students' insights.

6) The selection of learning media gets a score of 19 with a percentage of $79.16 \%$ and very good assessment criteria. In this case the reviewer considers the chosen media is appropriate by involving the use of IT in the form of a device in the form of a laptop equipped with images related to the material.

7) An aspect of the learning model gets score of 14 with a percentage of $87.50 \%$ and very good assessment criteria. Reviewers consider the use of problem-based learning models very appropriate to be applied in exposition text writing material.

8) The learning scenario gets a score of 24 with a percentage of $75 \%$ and the assessment criteria are good.

9) The assessment / evaluation aspect gets score of 24 with a percentage of $75 \%$ and the assessment criteria are good. Comments given by reviewers include increasing the number of questions, improving assessment instruments and assessment criteria in the realm of knowledge (cognitive).

In general, of the nine aspects that have been given to reviewers through questionnaires, the quality of learning design has been very good with an average score of $80 \%$ in the range of the percentage score of $75 \% \leq \mathrm{X} \leq 100 \%$ with the criteria Very Good. 
In addition to assessing the learning design, assessment is also carried out for teaching materials used in the development of problem-based learning models. The assessment was given by two fellow teachers in the field of Indonesian language studies to get improved quality. The score for peers' assessment of teaching materials can be seen in table 4.4 below:

Table 4. Peer Assessment Scores for Teaching Material

\begin{tabular}{|c|c|c|c|}
\hline \multirow[b]{2}{*}{ NO } & \multirow[b]{2}{*}{ Indicators } & \multicolumn{2}{|c|}{ Study Results / Scores } \\
\hline & & Reviewer 1 & Reviewer 2 \\
\hline \multicolumn{4}{|c|}{ A. Relevance } \\
\hline 1 & $\begin{array}{l}\text { The material is relevant to the competencies that must be } \\
\text { mastered by students }\end{array}$ & 4 & 4 \\
\hline 2 & $\begin{array}{l}\text { The task is relevant to the competencies that must be } \\
\text { mastered }\end{array}$ & 3 & 3 \\
\hline 3 & $\begin{array}{l}\text { Examples are relevant to the competencies that must be } \\
\text { mastered }\end{array}$ & 3 & 3 \\
\hline 4 & $\begin{array}{l}\text { The exercises and questions are relevant to the } \\
\text { competencies that must be mastered }\end{array}$ & 3 & 4 \\
\hline 5 & $\begin{array}{l}\text { Depth of description in accordance with the level of } \\
\text { student development }\end{array}$ & 3 & 3 \\
\hline 6 & $\begin{array}{l}\text { Completeness of the description of the material in } \\
\text { accordance with the level of student development }\end{array}$ & 3 & 3 \\
\hline 7 & $\begin{array}{l}\text { Description material is enough to meet the demands of the } \\
\text { curriculum }\end{array}$ & 3 & 3 \\
\hline 8 & Enough amount of exercise & 3 & 3 \\
\hline 9 & Enough amount of tasks & 3 & 3 \\
\hline \multicolumn{4}{|c|}{ B. Accuracy } \\
\hline 10 & $\begin{array}{l}\text { The material presented is in accordance with scientific } \\
\text { truth }\end{array}$ & 3 & 3 \\
\hline 11 & $\begin{array}{l}\text { The material presented is in accordance with the latest } \\
\text { developments }\end{array}$ & 3 & 3 \\
\hline 12 & The material presented in accordance with everyday life & 4 & 4 \\
\hline 13 & $\begin{array}{l}\text { Packaging material in accordance with scientific } \\
\text { development }\end{array}$ & 3 & 3 \\
\hline \multicolumn{4}{|c|}{ C. Completeness of Serving } \\
\hline 14 & Presenting competencies students that must be mastered & 3 & 3 \\
\hline 15 & $\begin{array}{l}\text { Presenting the benefits and importance of mastering } \\
\text { competencies for life }\end{array}$ & 3 & 3 \\
\hline 16 & Presenting sources of reference / writing references & 3 & 3 \\
\hline \multicolumn{4}{|c|}{ D. Serving Systematics } \\
\hline 17 & $\begin{array}{l}\text { Material description follows the flow of thinking from } \\
\text { simple to complex }\end{array}$ & 3 & 3 \\
\hline \multicolumn{4}{|c|}{ E. Conformity with Student-Centered Learning } \\
\hline 18 & Encourage students' curiosity & 3 & 4 \\
\hline 19 & Encourage interaction & 4 & 4 \\
\hline 20 & Encourage students to build their own knowledge & 3 & 3 \\
\hline 21 & Encourage students to learn in groups & 4 & 4 \\
\hline
\end{tabular}




\begin{tabular}{|r|l|l|l|}
\hline F. Serving method & 3 & 3 \\
\hline 22 & Supporting piety to God Almighty & 3 \\
\hline 23 & Supporting awareness of the diversity of the community & 3 & 3 \\
\hline 24 & Supporting the growth of nationalism & 3 & 3 \\
\hline 25 & Supporting the emergence of local wisdom & 3 & 3 \\
\hline 26 & Supporting logical thinking based on experience & 4 & 3 \\
\hline G. Suitability of Language with EYD Rules & 3 & 3 \\
\hline 27 & Accuracy in spelling & 3 \\
\hline 28 & Accuracy in choosing terms & 3 \\
\hline 29 & Accuracy in structuring sentences & 3 & 3 \\
\hline H. Communicability & 3 \\
\hline 30 & $\begin{array}{l}\text { The length of the sentence according to the level of } \\
\text { understanding of students }\end{array}$ & 3 \\
\hline 31 & $\begin{array}{l}\text { Sentence structure according to the level of understanding } \\
\text { of students }\end{array}$ & 3 \\
\hline 32 & $\begin{array}{l}\text { The language used is not too rigid (half formal) so it is } \\
\text { easy for students to digest }\end{array}$ & 3 \\
\hline Total score & $\mathbf{1 0 1}$ & $\mathbf{1 0 2}$ \\
\hline Average Number of Scores & $\mathbf{7 8 , 9 0 \%}$ & $\mathbf{7 9 , 6 8 \%}$ \\
\hline Average Percentage Score & $\mathbf{7 9 , 2 9 \%}$ & \\
\hline
\end{tabular}

Based on the data obtained from the results of peer examinations (reviewer) obtained the quality of learning teaching material as outlined in the form of teaching materials worth $79.29 \%$ is in the range of scores of $75 \% \leq \mathrm{X} \leq 100 \%$ with criteria Very Good.

The results of the needs analysis showed that all teachers (two teachers) knew the problem based learning model while all students (17 students) did not understand the problem based learning model. Therefore, researchers explain to students about the description of the model so that students gain understanding and research can proceed to the next stage. All teachers have used the problem based learning model in learning to write text and all students do not understand that the teacher has used the problem based learning model in learning. All teachers said that they needed the use of problem based learning models and 13 students $(76 \%)$ responded to the need to use this problem based learning model. All teachers were happy with the use of the problem based learning model and 14 students were happy with the use of the problem based learning model. Most respondents (82\%) said they were motivated to participate in learning by using problem-based learning models. Based on the needs analysis that has been done, it can be concluded that the learning model used so far has not been in accordance with the needs of students and teachers. Teachers and students of VIII grade in Junior High School of Methodist 12 Medan need a practical model and make it easier for students in learning the exposition text writing.

The second stage is design. In this design stage, the researcher prepares the initial product or product design. In the context of developing a learning model, this stage is filled with the activity of preparing a conceptual framework for developing a problem-based learning model that is the initial design of the learning implementation plan and initial validation by the teacher or colleague. The instruments needed to get validation at this stage are questionnaire sheets on the validation of the content and feasibility of learning material. Furthermore, peers check the products that have been developed to get more complete data. After that, colleagues give 
improvements to parts that are considered unfavorable. After being considered good, it is then tested on students.

The third stage is the development stage. The development stage aims to produce revised products based on expert input. At this stage the data collection was carried out in the form of validation of the development of problem-based learning models with learning implementation plan design products contained in the guidelines and implementation of the development of problem-based learning models on exposition text writing material to VIII grade students of Junior High School Methodist 12 Medan.

The fourth stage is dissemination. The dissemination stage is the final stage in the 4-D process developed by Thiagarajan (1974). At this stage of dissemination in the form of stages of the spread of learning models that have been developed and have been assessed for their feasibility can be disseminated or used by teachers in learning.

\section{Conclusion}

The development process of problem based learning model on exposition text writing material for eighth grade students of Junior High School Methodist 12 Medan is in general the aspects of the assessment given by reviewers, the product design of the problem based learning model development has been very good with an average score of overall acquisition of $80 \%$ with very good assessment criteria.

\section{References}

Arikunto, S. (2010). Prosedur Penelitian Suatu Pendekatan Praktik. Jakarta: Rineka Cipta. Asyiqin, N, et al. (2018). Pengaruh Model Problem Based Learning (PBL) Terhadap Keterampilan Menulis Teks Eksposisi. e-Journal FBS Universitas Negeri PadangPendidikan Bahasa dan Sastra Indonesia (Volume 1 of 2018).

Bintari, N., L., G, et al. (2014). Pembelajaran Bahasa Indonesia Berdasarkan Pendekatan Saintifik (Problem Based Learning) sesuai Kurikulum 2013 di Kelas VII SMP Negeri 2 Amlapura. e-Jurnal Program Pascasarjana Universitas Pendidikan Ganesha SingarajaProgram Studi Pendidikan Bahasa (Volume 3 Tahun 2014).

Daryanto. (2014). Pembelajaran Tematik Terpadu, Terintegrasi (Kurikulum 2013). Jakarta: Gava Media.

Fathurrohman, M. Model-Model Pembelajaran Inovatif. Yogyakarta: Ar-Ruzz Media. Hamalik, O. (2010). Proses Belajar Mengajar. Jakarta: PT Bumi Aksara. Hamruni. (2012). Strategi Pembelajaran. Yogyakarta: Insan Madani. Hizati, A, et al. (2018). Pengaruh Model Problem Based LearningBerbantuan Media Gambar BerseriTerhadap Keterampilan Menulis Teks EksplanasiSiswa Kelas VIII SMP Negeri 12 Padang. e-Journal FBS Universitas Negeri PadangProgram Studi Pendidikan Bahasa dan Sastra Indonesia (Volume 1 Tahun 2018)

Kementrian Pendidikan dan Kebudayaan. (2013). Salinan Peraturan Menteri Pendidikan dan Kebudayaan. Jakarta: Kementrian Pendidikan dan Kebudayaan.

Kementrian Pendidikan dan Kebudayaan. (2014). Salinan Peraturan Menteri Pendidikan dan Kebudayaan. Jakarta: Kementrian Pendidikan dan Kebudayaan. 
Kementrian Pendidikan dan Kebudayaan. (2014). Permendikbud Nomor 104 tahun 2014 tentang Penilaian Hasil Belajar Oleh Pendidik Pada Pendidikan Dasar dan Pendidikan Menengah. Jakarta: Kementerian Pendidikan dan Kebudayaan RI.

Kosasih, E. (2011). Ketatabahasaan dan Kesusasteraan. Bandung: Yrama Widya.

Kosasih, E. (2014). Jenis-jenis Teks: Analisis Fungsi, Struktur, dan Kaidah serta Langkah Penulisannya. Bandung: Yrama Widya.

Kurnia. (2015). Penerapan Model Problem Based Learning untuk Meningkatkan Kemampuan Menulis Teks Eksposisi. e-Jurnal Program Pascasarjana UNASMAN (Volume 9 of 2015)

Mahsun. (2014). Teks dalam Pembelajaran Bahasa Indonesia Kurikulum 2013. Jakarta: Raja Grafindo Persada.

Nafiah, Y., N. (2014.) Penerapan Model Problem-Based Learning untuk Meningkatkan Keterampilan Berpikir Kritis dan Hasil Belajar Siswa. e-Jurnal Program Studi Pendidikan Teknologi dan Kejuruan PPs UNY (Volume 4 Tahun 2014)

Permana, G. (2015). Pengembangan Model Pembelajaran Berbasis Masalah Menggunakan Software Macromedia Flash 8 pada Mata Pelajaran Instalasi Penerangan Listrik untuk Meningkatkan Hasil Belajar Peserta Didik di Kelas XI TIPTL SMK Negeri 1 Nganjuk. e-Jurnal Fakultas Teknik, Universitas Negeri SurabayaProgram Studi Teknik Elektro (Volume 4 of 2015)

Priyatni, I., T. (2014). Desain Pembelajaran Bahasa Indonesia. Jakarta: Bumi Aksara.

Rusman. (2017). Model-model Pembelajaran: Mengembangkan Profesionalisme Guru. Jakarta: Rajawali Pers.

Sani, R. (2013). Inovasi Pembelajaran. Jakarta: PT. Bumi Aksara.

Sanjaya, W. (2014). Strategi Pembelajaran: Berorientasi Standar Proses Pendidikan. Jakarta: Kencana Prenadamedia Group.

Shoimin, A. (2018). 68 Model Pembelajaran Inovatif dalam Kurikulum 2013. Yogyakarta: ArRuzz Media.

Sugiyono. (2012). Metode Penelitian Kualitatif, Kuantitatif, dan R\&D. Bandung: Alfabeta

Suparno. (2008). KeterampilanMenulis. Jakarta: PT. Universitas Terbuka.

Tarigan, J. (2018). Penerapan Model Pembelajaran Berbasis Masalah dengan Bantuan Media Video untuk Meningkatkan Keterampilan Menulis Teks Eksplanasi. e-Journal Jurusan Pendidikan Bahasa Indonesi, Bali (Volume 2 Tahun 2018)

Trianto. (2018). Mendesain Model Pembelajaran Inovatif-Progresif. Jakarta: Kencana.

Tyas, R. (2017) Kesulitan Penerapan Problem Based Learning dalam Pembelajaran Matematika. e-Journal Program Studi Akuntansi Universitas Kahuripan Kediri (Volume 2 of 2017). 